\title{
Possible Worlds of Planet Solaris: The Reader's Consciousness in the Condition of Indeterminacy
}

\begin{abstract}
Grebeniuk Tetiana, Possible Worlds of Planet Solaris: The Reader's Consciousness in the Condition of Indeterminacy [Światy możliwe planety Solaris: świadomość czytelnika w warunkach nieoznaczoności]. „Przestrzenie Teorii” 33. Poznań 2020, Adam Mickiewicz University Press, pp. 209-227. ISSN 1644-6763. DOI 10.14746/pt.2020.33.10.
\end{abstract}

The article examines the specifics of the reader's reception of Stanisław Lem's novel Solaris in the context of indeterminacy, and the openness of the work to interpretation. The paper examines literary approaches to the formation of meaning in the process of reading this novel, in particular those implemented in Manfred Geier and Istvan Jr. Csicsery-Ronay works. Marie-Laure Ryan's adaptation of the theory of possible worlds to literary analysis is employed as the methodological basis of my research. On the one hand, the effect of indeterminacy corresponds to the fantastic nature of the conditionality of Lem's novel. Indeed, the key issue of the work - the encounter of humans with the unknown - requires the author to apply the potential of secrecy. On the other hand, this highly literary work (as well as Andrei Tarkovsky's film adaptation) is endowed with multiple and ambiguous semantic codes that appeal to the depths of human consciousness and the unconscious. These codes cannot be interpreted unambiguously and, therefore, also provoke a state of uncertainty in the reader. In the textual actual world, semantic codes produce indeterminacy. They are linked to the essence of the single inhabitant of the Solaris, the Ocean, and phantoms created by it who visit the Station. In the novel protagonist's Kris Kelvin personal world, the state of indeterminacy is associated with the existential essence of his relationship with his beloved Rheya and the problem of making contact with extraterrestrial intelligence. The surreal imagery of Kris's dreams and visions provide for possible interpretations of the semantic codes of his world.

KEYWORDS: Lem, narrative, possible worlds theory, indeterminacy

\section{Introduction}

Stanislaw Lem's novel Solaris fully deserves to be considered one of the vertex works of science fiction. It sets various philosophical and moral-ethical problems of modern times. In essence, the novel legitimizes the incognizability, the incompleteness, the indeterminacy as principles of relations between the human mind and the Universe. These indeterminacy and semantic incompleteness of the text stimulate additional meaning-making recipient's activity while reading - activity resulting sometimes in endowment of the text with multiple meanings, even those that the author did not imply. 
Stanislaw Lem himself in his work Fantastyka i futurologia evaluates the aspiration to create polysemic, indeterminate artistic structures as characteristic of the twentieth-century manifestation of literature's ambition for self-sufficiency ${ }^{1}$. The writer skillfully exploits the means of creating the effect of indeterminacy in his fictional works. Researchers ${ }^{2}$ have repeatedly noted the interpretative openness of Lem's works, which is achieved not least by the reader's hesitation, doubt, and uncertainty regarding the facts of the textual world ${ }^{3}$.

This paper aims to analyze the sources and means of creating the indeterminacy effect in Lem's science fiction novel Solaris, as well as to investigate cognitive mechanisms of the reader's perception of indeterminacy in the context of literary adaptation of possible world theory by Marie-Laure Ryan.

\section{Discourse of Solaris: a look under the veil of Maya}

Analyzing how the indeterminacy is suggested into the reader's mind when reading Solaris, one should pay special attention to the genre-specific nature of the reader's doubts and hesitations.

Recognizing the science fiction base in the genre structure of the novel of the Polish writer, it should be noted that the receptive aspect of its functioning allows us to interpret the work as a manifestation of literary fantastic according to the concept of Tzvetan Todorov.

Tzvetan Todorov in his work The Fantastic: A Structural Approach to a Literary Genre stresses that the fantastic concentrates on the reader's state of indeterminacy, his or her demurrings between rational and irrational explanations of a certain phenomenon or event. "The fantastic is that hesitation experienced by a person who knows only the laws of nature, confronting an apparently supernatural event" ${ }^{\prime \prime}$ - the researcher outlines.

${ }^{1}$ S. Lem, Fantastyka i futurologia, vol. 2, Kraków 1970.

${ }^{2}$ I.Jr. Csicsery-Ronay, The Book Is the Alien: On Certain and Uncertain Readings of Lem's "Solaris", "Science-Fiction Studies" 1985, no. 12, (1), p. 6-21; M. Geier, Stanislaw Lem's Fantastic Ocean: Toward a Semantic Interpretation of "Solaris", "Science-Fiction Studies" 1992, no. 19 (2), p. 192-218; K.N. Hayles, Chaos as Dialectic: Stanislaw Lem and the Space of Writing, "Chaos Bound: Orderly Disorder in Contemporary Literature and Science", Ithaca and London 1990, p. 115-140; І.Б. Кияк, Жанрові особливості фбантастики і фбутурології Станіслава Лема, Автореферат дисертації на здобуття наукового ступеня к.ф.н., Київ 2001.

${ }^{3}$ Csicsery-Ronay writes that Lem's novel Solaris can be read "as a Swiftian satire, a tragic love story, a Kafkaesque existentialist parable, a metafictional parody of hermeneutics, a Cervantean ironic romance, and a Kantian meditation on the nature of human consciousness" (I.Jr. Csicsery-Ronay, op. cit., p. 7).

${ }^{4}$ T. Todorov, The Fantastic: A Structural Approach to a Literary Genre, Cleveland-London 1973, p. 25. 
When considering the reception of fantastic, Todorov puts to the question the obligatoriness of the reader's identification with a particular character. As a consequence, he states that the fantastic genre "may exist without satisfying this condition; but it will be found that most works of fantastic literature are subject to it"s.

According to Todorov, the reader's hesitation is the first of three conditions of the fantastic genre functioning. The second one is the similar demurrings of the hero who becomes the subject of the description in the work. Finally, the third condition is the existence of a certain attitude to the text, which eliminates the possibility of allegorical and "poetic" interpretation of it ${ }^{6}$. The researcher considers the first and third conditions to be the obligatory ones, whereas the second one appears to be optional.

In the case of Solaris, all three conditions of the fantastic genre functioning are present, therefore the state of indeterminacy in the course of reading of the entire novel can be analyzed in the context of the novel fantastic nature.

In literary studies of Stanislaw Lem's fiction, the problem of indeterminacy has already attracted scholar's attention in various contexts and in connections with various concepts. For example, Jerzy Jarzebski consideres indeterminism (together with determinism) of human life as one of the constant themes of the writer's works ${ }^{7}$. Katherine N. Hayles in her investigation of dialectical connections of order and disorder in Lem's writings, views the writing process itself as focused "on the open-endedness of the process anything may happen, infinite possibilities lie open to the creator, chance fluctuations create situations whose outcomes cannot be foreseen"8, understanding the author's heritage as a space of dialectical connection of indeterminacy (chaos) and order. Piotr Krywak discovers in the Solaris structural elements of the criminal novel poetics, notably its manipulation with puzzles and mysteries. The researcher demonstrates the way "[a] criminal puzzle turns into a cognitive one"9 in the novel. Peter Swirski consideres the fulcrum of Solaris in "drama of the encounter with the unknown"10. That's why for him the main explanation of incomprehensibility of some text elements is "manifestation of alien intelligence" in it.

${ }^{5}$ Ibid., p. 32.

${ }^{6}$ Ibid., p. 33.

${ }^{7}$ J. Jarzebski, Stanislaw Lem: Rationalist and Visionary, transl. F. Rottensteiner, "Science-Fiction Studies" 1977, no. 4, p. 110-126.

${ }^{8}$ K.N. Hayles, op. cit., p. 119.

${ }^{9}$ P. Krywak, Fantastyka Lema: droga do "Fiaska", Kraków 1994, p. 33.

${ }^{10}$ P. Swirski, Solaris! Solaris. Solaris?, [in:] The Art and Science of Stanislaw Lem, ed. P. Swirski, Montreal \& Kingston-London-Ithaca 2008, p. 175. 
It should be noted that the above-mentioned researches by J. Jarzebski, K.N. Hayles and P. Krywak are accomplished generally from the position of text creation, with concentration on the author's personality. P. Swirski in his investigation takes into account receptive aspect of text functioning ${ }^{11}$ but he has no aim to trace the specific cognitive mechanisms of the indeterminacy influence instead of it inspiring other sholars to apply to the Lem's works diverse up-to-date methods of analysis.

So far as in this paper the basis of the approach to the text is a cognitive aspect of the reader's perception it is worthwhile paying special attention to the Solaris studies undertaken by Manfred Geier and Istvan Jr. Csicsery-Ronay containing ideas relevant to this approach.

Manfred Geier in his interview to Edith Welliver draws attention to the ways of meaning formation when reading of the science-fiction novel. Stanislaw Lem's Solaris Geier identifies as “...one of the most interesting, best conceived, and most suspenseful novels in all SF"12.

Focusing on the description of the Ocean as the thematic center of the novel, the scholar raises a double question: what the Ocean itself means, and how Lem manages to describe it semantically and explain the non-existent in reality phenomenon?

Geier points to the paradox of the text structuring which alongside with the process of its reception corresponds to the collision between the linguistically unexpressed, meaningless nature of the Ocean and, at the same time, the fact that it is the subject of action in the narrative, its objective reality due to the rich in meanings textual referentiality ${ }^{13}$.

Whereas Geier does not recognize the world of Solaris completely autonomous, he considers it as a fictional model of reality created by the means of an unusual arrangement of linguistic elements, for each of which, however, the competent reader sees certain predictions. Indeed, in Lem's text all the elements are expressed in clear words, grouped into adequate syntactic combinations. Thus, even the most extravagant fictional forms here are linked to reader's experience, and therefore to the awareness of the probable models of reality and, consequently, the forms of narration created with linguistic expressions and textual links, sometimes with the help of symbols.

Istvan Jr. Csicsery-Ronay appraises Lem's novel as "one of the philosophically most sophisticated works of SF"14 and considers it as a detailed

${ }^{11} \mathrm{P}$. Swirski even finishes his work with the pep talk "Take Solaris about three times a day and see what it can do for you", ibid., p. 178.

${ }^{12}$ M. Geier, op. cit., p. 193.

${ }^{13}$ Ibid., p. 198.

${ }^{14}$ I.Jr. Csicsery-Ronay, op. cit., p. 7. 
metaphor of the cultural and philosophical implications of the scientific doubts of Western culture ${ }^{15}$.

The researcher focuses on the moments of the work which are not amenable to interpretation. Taking into account the homodiegetic nature of the narrative in the novel, Csicsery-Ronay argues: "Still, the fundamental indeterminacy of Solaris will not let us accept any interpretation based only on what Kelvin, our sole informant, tells us"16. Analyzing the receptive aspect of the novel's functioning, the scholar, in tune with Todorov's theory, admits that the protagonist's uncertainty and the reader's uncertainty are based on the principle of "box in box": "... as the indeterminacy of Solaris deflects its explorers back into doubt about their methods of interpreting phenomena, the indeterminacy of the evidence in Solaris deflects us back into doubt about our own methods of reading"17.

The scholar maintains that the protagonist's statements, even fully conscious, cannot be trusted, as he, like all the other solarists ("desperate men"), faces not only the unknowable alien reality, but also close and unattractive materializations of themselves embodied in the images of "visitors" 18 .

Finally, Csicsery-Ronay extremely exacerbates the effect of doubt, the recipient's indeterminacy, by inquiring whether Solaris is a collective hallucination of the humanity generated by its subconscious. Or, on the contrary, the human race is a hallucination or a dream of "ocean-yogi" Solaris, associated with the Hindu concept of Maya ${ }^{19}$.

The researcher also attempts to explain literary techniques that provide a special acuity to the perception of uncertainty. He appeals to Lem himself for whom the core of the novel is based on peculiar sociocultural and artistic-aesthetic components that the experienced reader is already aware of, as they are "taken from the repertoire of culturally known situation" ${ }^{20}$. Consequently, they provide the reader with the notion of "the repertoire of possible issues appropriate for [them]"; however, incorrectly combined, they appear to the recipient as "perforated, softened, and bent" with respect to each other. Respectively, the reader finds him/herself in a reading situation in which " $[\mathrm{t}]$ he hard opacity of the unyielding secret is complemented by the nauseating fluidity of the familiar when facing that opacity"21.

\footnotetext{
${ }^{15}$ Ibid.

${ }^{16}$ Ibid., p. 12.

${ }^{17}$ Ibid.

${ }^{18}$ Ibid., p. 13.

${ }^{19}$ Ibid.

${ }^{20}$ Ibid., p. 15.

${ }^{21}$ Ibid.
} 
Thus, the textual mystery and vagueness of Solaris, the novel, encourages scientists to employ various approaches and analysis methodologies for its research (by creating fractal copies of solarists' in-text attempts to reveal the secrets of the Ocean). To this scientific polyphony we give our voice as we are investigating the mechanisms of indeterminacy production from the perspective of the possible worlds theory.

\section{Possible Worlds Theory via Indeterminacy Effect}

The first attempts to use the achievements of the multidisciplinary theory of possible worlds in Literary Studies was undertaken in the 1970s. They originated from the scholars' dissatisfaction with the methodology of studying of the fiction world based on mimetic theory and the phenomenon of fictional reference. The symbolic nature of the denoted in literary texts appeared to be the most controversial: whether the literary text represents extratextual reality, or only itself, or it represents anything else?

David Lewis, Thomas Pavel, Umberto Eco, Lubomir Doležel, Ruth Ronen and Marie-Laure Ryan proposed diverse approaches to narratological analysis of the text employing ideas of the theory of possible worlds which later developed into the theory of fictional worlds, with a corresponding change in the object of study. Hereinafter we will briefly summarize some ideas articulated in their papers where indeterminacy is presented as an autonomous object of analysis.

Lubomir Doležel views the world of a literary work not as the one that reflects reality but the one that possesses an ontological status of an open possibility. The reader receives access to this world through semiotic channels by replicating forms previously constructed by the author. The researcher names the author's text "a set of instructions" for the readers following which they reconstruct the world ${ }^{22}$.

Ruth Ronen in Possible Worlds in Literary Theory plunges into the analysis of the problem of the fundamental incompleteness of the fictional worlds and considers the gaps as a component of this effect. She focuses on the fact that the reader tries to evaluate the world of a literary work as analogues of the actual world, similarly holistic, complete in details, fully accessible to cognition. Ronen credits the text's incompleteness as the very distinct characteristic of the literary world, contrasted to the non-textual one. "Incompleteness reflects on both logical and semantic aspects of fictionality: it has to do with the essential status of fictional objects and with the

${ }^{22}$ L. Doležel, Heterocosmica. Fiction and possible worlds, Baltimore 1998, p. 83. 
verbal mode of their construction" ${ }^{23}$, she claims. The scholar believes that the reader is free in choosing the way of how to "engross" a literary world: either as a complete replica of the reality or as a fundamentally incomplete mental model that is being perceived under aesthetic laws.

Marie-Laure Ryan suggests her own system of narrative worlds. She defines a being-told-about world as a "textual actual world" (TAW) in which the narrator presents external, physical facts. This world becomes an ontological center for characters' personal worlds that are centered around their experience of TAW and an epistemic world, or world of knowledge. Moreover, each characters' experience may contain gaps, limitations, and inaccuracies, but each of them perceives their personal world as the only real one. Likewise, the characters' worlds of desires, wishes (W-world) and obligations (O-world) and fantasy worlds can also acquire particular significance. The character can realize itself in dreams, visions and hallucinations, which, in turn, can form new separate modal systems ${ }^{24}$.

The listed varieties of personal worlds of one character or personal worlds of different characters can come into conflict. At last, Ryan views the very course of narration as the heroes' deeds aimed at shortening the distance between their model worlds and the real worlds. The researcher characterizes the reader's activity as a process of sorting out of the factual and physical from the possible and virtual in the system of all narrative worlds. She draws a conclusion: "Readers are not always-indeed, rarely-able to fill out all of the component worlds of the narrative universe, but the better they fill them out, the better they will grasp the logic of the story and the better they will remember the plot" 25 .

By now possible worlds theory is widely used in humanities and, in particular, in literary researches. The full testimony of this assertion is a book Possible Worlds Theory and Contemporary Narratology edited by Alice Bell and Marie-Laure Ryan in 2019 and containing new theoretical trends of the theory development and individual case studies ${ }^{26}$. Important task of the edition is to offer new ways of application of the theory in "postclassical" narratology, after "cognitive turn" in its course.

Understanding of cognitive potential of this theory and its convenience for analysis of the novel the artistic world of which is based on the idea of

\footnotetext{
${ }^{23}$ R. Ronen, Possible Worlds in Literary Theory, Cambridge 1994, p. 115.

${ }^{24}$ M.-L. Ryan, Possible Worlds, [in:] Living Handbook of Narratology, <https://www.lhn. uni-hamburg.de/node/54.html> [retrieved: 12.01.2020].

${ }^{25}$ Ibid.

${ }^{26}$ M.-L. Ryan, A. Bell, Introduction: Possible Worlds Theory Revisited, [in:] Possible Worlds Theory and Contemporary Narratology, eds. A. Bell and M.-L. Ryan, Lincoln and London 2019, p. 1-43.
} 
indeterminacy, option on both the plot level and the character psyche level conditions the choice of the Marie-Laure Ryan theory of fictional worlds as a methodology of study in this article.

\section{Personal World of Kris}

Solaris, the novel, focuses on events which happen at the research station of the planet Solaris, probably endowed with an incomprehensible for earthlings form of consciousness. For a prolonged period of time, scientists have been trying unsuccessfully to make a contact with the only inhabitant of the planet, the Ocean. In the evening before Kris Kelvin's, the narrator, arrival, the planet influenced by hard X-ray exposure starts sending Phi-creatures to the station residents. These creatures created on the deepest levels of subconsciousness are associated with the sexual desires or the feeling of guilt. At the core of the novel, there are relationships between Kris and his phantom visitor - the image of his wife Rheya ${ }^{27}$, who died long ago through his fault. At the level of the external events, Kris's aspiration to stay with Rheya comes in conflict with Snow and Sartorius' decision to exterminate all the guests of the station. Eventually, Snow and Sartorius succeed and Kris, being hard-pressed for the loss of his beloved, stays on Solaris to continue his search for the contact with the planet inhabitant.

In the light of the fictional worlds theory by Marie-Laure Ryan, the real textual world in the novel is the world of Solaris research station which drifts above the surface of the eponymous planet. In this world, apart from Kris, the cybernetics Snow and the physicist Sartorius operate, as well as Kris's visitor, Rheya, whose ontological status requires further clarification.

The characters' personal worlds are described disproportionately. Whereas Kris's world is pictured in great detail, even in its several dimensions, the worlds of Snow and Sartorius are fragmented since the readers are not even informed of who their visitors are.

In concern with Kris's world, the reader is told plainly of the protagonist's relationship with Rheya and his exploration of the planet Solaris. Actually, this is the existential core around which Kris's life is centered at the Station (and possibly beyond) ${ }^{28}$.

${ }^{27}$ In cited here English translation of the Polish text by Joanna Kilmartin and Steve Cox the original name Harey is turned into Rheya, and the name Snaut is changed into Snow.

${ }^{28}$ Indeed, a broader approach to the literary work allows for the conclusion that it is focused exclusively on the Contact issue because Rheya's appearance can be regarded as one of the first stages of Kelvin's communication with the Ocean. 
The reader senses that these spheres are of exeptional importance in the protagonist's being since he dwells on them anxiously. Placing the character into a situation of indeterminacy, Lem develops both aspects of it: external (fictional events, their contexts and circumstances) and internal (character's emotional experience of them). Yet, it is impossible to miss that in terms of fullness and receptive influence, internal indeterminacy plays a significantly greater intrinsic role in the novel. The author dwells in rich detail on Kris's experiences, describes his emotions and affects, and sends the reader signals about the importance of events and emotions.

Kris's personal world includes events narrated in the first person. his prospect of seeing and evaluating other characters and himself, the interiors of the station and landscapes of Solaris, a retrospective presentation of his previous experiences and perspective plans for the future, as well as the most significant elements of the hero's worldview.

Noteworthy, the obsession with extraterrestrial contact dominates Kris's worldview system and is related directly to studies of Solaris as well as Kris's daily activities at the station. Naturally the very essence of this problem - facing the unknown by a human being - involves the hero's passing through states of indeterminacy (some of them are removed or reduced afterwards but some stay unresolved).

Yet, indeterminacy of other kind disturbs Kris. His relationship with Rheya, both the earthly one and his visitor on Solaris, concerns him. At first, the new Rheya's arrival raises doubts about her origin and ontological status, i.e. at the beginning Kris perceives her as a manifestation of the unknown. But subsequently, this uncertainty acquires a completely "human", moral and ethical nature and resolves into hesitation regarding Rheya's role in his life, their future together.

In Kris Kelvin's personal world, the indeterminacy of the two mentioned above varieties occupies an important place in the emotional and motivational sphere of the hero's personality and is distinguished by its own dynamics. Further, we will consider the dynamic aspects of this indeterminacy and its function in the literary work plot.

Indeterminacy is triggered in Kris through the signs of dereliction of the station interiors, the mysterious death of Gibarian and the improper behavior of Snow and Sartorius. Chapter One of the novel shows the hero's insecurity and anxiety caused by these factors. Kris's awareness of an outsider presence intensifies further tension and petrifies him: “... I had a sudden sensation of being watched. I was still leaning over the map, but I no longer saw it; my limbs were in the grip of a sort of paralysis. ... My back and my neck seemed to be on fire; the sensation of this relentless, fixed 
stare was becoming unbearable" 29 . At this very moment, the manifestations of the hero's physiological reactions to incomprehensible (therefore terrible) phenomena gain pivotable importance in portraying his psychological state. Thus, for instance, awareness of Sartorius and Gibarian's visitors reality makes him physically numb. The library appears to be the only place at the station where Kris feels emotionally comfortable ${ }^{30}$.

Omitting the textual description of Snow and Sartorius's visitors, Lem creates significant semantic lacuna which strikes mystical horror since the unknown affects the recipient more than something articulated and shown directly. Moreover, the struggle of people with their guests stays in the shadows. Yet, details like blood on Snow's nails or Sartorius's anti-radiation gloves leave a wide field for speculations about the cruelty of their deeds and make an impact even stronger than possible specific descriptions.

Only in Chapter Four, Kris realizes the scale and comprehensiveness of the influence of the unknowable on the life of the station crew what results in his confusion and despair. Afterwards, accumulated negative emotions suddenly explode during his impulsive conversation with Sartorius - disproportionate and rude.

Later, the uncertainty resulting from the encounters with the incognizable exacerbates Kelvin's emotional reaction to an even greater extent, because now it is fuelled by the torturous memories emerging from the deepest levels of his subconscious, making the emotional perception unbearable. Rheya's visits activate the protagonist's emotions. Initially having survived complete bewilderment, Kelvin acts fast, almost automatically: he shoots the mysterious creature into orbit in a rocket.

Provoking horror in the readers while depicting the scene of Rheya's departure, the author endows this character with inhuman features:

I was greeted by a spectacle which I hope I shall never have to see again. The whole vehicle trembled, shaken from the inside as though by some superhuman force. [...] the intercom connected to the shuttle's interior gave out a piercing sound - not a cry, but a sound which bore not the slightest resemblance to the human voice, in

${ }^{29}$ S. Lem, Solaris, Harvest Books 1987, p. 25.

${ }^{30}$ The image of the library plays a crucial role in the novel - and not only because of the lack of windows but because of its isolation from the Ocean. On the whole, Lem's reverence for this image also reflects his worship of human knowledge. Consequently, in terms of the fictional world of Solaris, the "comfort" of the library in the middle of the mysterious alien space represents the comfort of rational knowledge as opposed to irrational indeterminacy of the Ocean. In the film version of Solaris by Andrei Tarkovsky, the coziness of this image is emphasized by the transformation of the library into the "room of psychological relief" and enhanced by its "earthly" look: tastefully selected with antique furniture, decor, and art objects. 
which I could nevertheless just make out my name, repeated over and over again: "Kris! Kris! Kris!" 1

For a second time, Kris's world is shattered by the experience of transgression, which he gains after Rheya's second visit. This moment in the plot development is critical as, on the one hand, it is a precursor of the contact with the Ocean what the hero is looking for, and, on the other hand, it epitomizes the experience of initiation, of dying in one status for the sake of being reborn in the other. Kris is enduring some liminal state, balancing on the edge of sleep and alertness:

As though from a distance, I heard the beating of my heart. I summoned up all my remaining strength, straining every nerve, and waited for death. I went on waiting. ...I tried to crawl out of bed, but there was no bed; beneath the cover of darkness there was a void. I pressed my hands to my face. I no longer had any fingers or any hands. I wanted to scream ${ }^{32}$.

Notably, that in the same Chapter Seven, Kris becomes affected by something that he calls „horror which exceeded anything I had felt hitherto" ${ }^{33}$. It goes about the vision of two identical dresses lying nearby - the clothes of the first and second Rheya. They represent incognizable, incomprehensible events and phenomena happening at the planet Solaris. Thus, the hero's mystical horror arises from this very link between the image and the incognizable, and this, by-turn, suggest the state of mystical horror to the reader.

Having embraced new Rheya, and having experienced the transgression, Kris adapts to life in the conditions of uncertainty and takes it as a necessary given. Snow characterizes a „renewed” hero as a person who is „doing all you can to stay human in an inhuman situation" ${ }^{34}$.

\section{The Mystery of Human (?) Relationship}

The Kris's doubts about future of his relations with Rheya is also a difficult object for reader's interpretation, so long as the reasons of protagonist's hesitation are not fully comprehensible and, thus, cause the reader's state of indeternimacy.

On the one hand, Kris demonstrates the unambiguity of his feelings for the beloved: "I can not tell the future any more than you can. I can not even swear that I shall always love you. After what has already happened,

\footnotetext{
${ }^{31}$ S. Lem, Solaris..., p. 64.

${ }^{32}$ Ibid., p. 87.

${ }^{33}$ Ibid., p. 93.

${ }^{34}$ Ibid., p. 151.
} 
we can expect anything. [...] It's out of our hands. But the decision we make today is in our hands. Let's decide to stay together" ${ }^{35}$, he says to Rheya.

However, even after this declaration, the protagonist's internal monologues prepare the reader for Kris's imminent rejection of Rheya. For instance, before having encephalography, Kris is afraid that, at a subconscious level, he might want Rheya to disappear. Furthermore, at the end of Chapter Ten, the reader of the novel can feel in the air the upcoming betrayal: "I had not yet resolved anything, or reached any decision. ... All I had was the grim certainty of having crossed some point of no return. I refused to admit that I was travelling towards what I could not reach. Apathy robbed me of the strength even to despise myself"' ${ }^{\prime 6}$. Having made the inner decision, both of the lovers - Kris and Rheya - feel that their relationship, stable at first glance, goes into a state of precarious equilibrium.

The reader faces a situation when the reasons for the protagonisn's intrapersonal conflict, his motifs appear indefinable for recognition. To begin with, subconsciously, a faulty model of Kris's relationship with women conditions his present determination to abandon Rheya, as well as his previous break up with the earthly Rheya. On the contrary, an explanation can be sought in the extraterrestrial incomprehensible nature of the present Rheya, which inevitably undermines the feelings of the protagonist. Notwithstanding how much Kelvin loves Rheya, the realization of the fact that she is a part of the chimeral nature of the Ocean never leaves him. Being convinced of his true love for the girl, he is not able to resist his denial of her otherness. This, for instance, is exemplified by Kris's loathing towards Rheya after she breaks through the door on the way to him: "First a face appeared, deathly pale, then a wild-looking apparition, dressed in an orange and black bathrobe, flung itself sobbing upon my chest. I wanted to escape, but it was too late, and I was rooted to the spot" ${ }^{37}$. Rheya is doomed to remain for Kelvin a teratomorphic being, a mysterious creature born by the Ocean.

By depicting the extreme vulnerability of the lovers' relationship, the author emphasizes the temporal perspective of Kris's narrative. The adverb "now" in the hero's reflection focuses the reader on the retrospectives of the narrative and the fact that at that moment, when the events were unfolding, Chris was unaware of the nature of his condition: "When I look back at those moments today, I have a strong conviction that this atmosphere of uncertainty and suspense, and my presentiment of impending disaster, was provoked by an invisible presence which had taken possession of the

\footnotetext{
${ }^{35}$ Ibid., p. 145.

${ }^{36}$ Ibid., p. 157.

${ }^{37}$ Ibid., p. 91.
} 
Station"38, - admits the hero. He also suggests that the cause of uncertainty may root in his dreams, the imaginative system of which can be interpreted as a detailed metaphor of the Contact.

Finally, the reasons why Kris chooses life without Rheya stay unclear and open for the reader, therefore the finale of the novel suggests diverse interpretations. It is worth saying that the mentioned above incomprehension is stressed in the novel as fundamental, this effect is achieved through a very accurate description of Kris's vision - his attempt to touch the Ocean: "the wave hesitated, recoiled, then enveloped my hand without touching it, so that a thin covering of 'air' separated my glove inside a cavity which had been fluid a moment previously, and now had a fleshy consistency"39.

"A thin covering of 'air", refers to the impossibility of analysis, the immanent features of the planet still stays incomprehensible for a human mind, and yet Kris considers his tragic experience with Rheya as a hint at the possibility of the contact with the Ocean, though not on his terms, and stays at the station.

Therefore, in the personal world of Kris, his experience is shaped like a spiral loop. Initially, indeterminacy underlined the beginning of his work on Solaris. Then, having suffered the circle of tragic individual experiences, the hero finds himself in the state of indeterminacy again. But now he takes it for granted and moves further to the other, more sensitive level of the search of the contact.

\section{The problem of the ontological status of Rheya}

Separate consideration must be given to the ontological status of Rheya in the context of indeterminacy as an attribute of the fictional worlds, and, consequently, to the quetison of the autonomy of her personal world.

Firstly, since Rheya is a product of Kris's memory, it might appear that we can not discuss her as a character with her own fictional world. Following her arrival, the reader becomes convinced of this by her deeds: she is always next to her "master", is never interested in anything and anybody, except him, she has no memories of her own. According to Snow, "[w]hen it arrives, the visitor is almost blank-only a ghost made up of memories and vague images dredged out of its [...] source. The longer it stays with you,

\footnotetext{
${ }^{38}$ Ibid., p. 178.

${ }^{39}$ Ibid., p. 203.
} 
the more human it becomes. It also becomes more independent [...]. And the longer that goes on, the more difficult it gets" ${ }^{40}$.

Rheya, like other visitors of the Station, is almost immortal and capable of reduplication provided one of her incarnations has lost a touch with the "owner", i.e. this creature is neither unique nor exceptional or self-sufficient.

Nevertheless, the humanization of Rheya, mentioned by Snow, forces Kris to change his attitude towards her gradually. Soon after her second arrival, the protagonist begins to treat the girl as an individuality: "I understood at that moment that she was not trying to deceive me; it was I who was deceiving her since she sincerely believed herself to be Rheya" ${ }^{41}$. Moreover, if at first, Kris views her as an identical copy of the earthly original, later, he admits that he no longer perceives her as a copy of her predecessor: "Now all I see is you"

Whereas the main features of Rheya (kindness, attentiveness, care) remain unchanged, her image develops promptly. In particular, she appears affectionate and insightful, easily "reads" personalities and states of people. Over time, Rheya develops a deeper capacity for reflection, she senses the indeterminacy in their relationship and perceives her very status as a destructive factor. In some mysterious way, she manages to go beyond the boundaries of Kris's world and puts to analysis, as if from the outside, her role and destination at the station: "I searched myself for ... you know, some sign of 'influence' I was going mad. I felt as if there was no body underneath my skin and there was something else instead: as if I was just an illusion meant to mislead you. You see?"43

Although Rheya is a product of Kris's psyche, eventually she starts bearing secrets from him (like listening to Gibarian's recording and discussing her prospects with Snow ${ }^{44}$ ). In the end, the girl sacrifices the most valuable that she has - her opportunity to stay with Kris - for his good. It can be said that Rheya's world has finally self-determined from the world of Kris and acquired intrinsic value.

${ }^{40}$ Ibid., p. $149-150$.

${ }^{41}$ Ibid., p. 92.

${ }^{42}$ Ibid., p. 146.

${ }^{43}$ Ibid., p. 143.

${ }^{44}$ Tarkovsky in his film adaptation of Solaris, adds to Lem's pieces of evidence some of his own, which demonstrate Rheya's humanization. In particular, the girl is shown as the subject of aesthetic reception when she takes a long and thoughtful look at the reproduction of Pieter Bruegel's "The Hunters in the Snow". In this way, she individually comprehends the secret of Art and pictures the Earth, which she has never seen before. Kris even has to address her twice to get her out of a contemplative stupor. Furthermore, Rheya actively expresses her opinion in a conversation with Snow and Sartorius defending her right to be called a human. 


\section{Semantics of Oneiric Images}

Connected with the effect of indeterminacy, the world of dreams becomes crucial as a manifestation of Kris's fantasy world ${ }^{45}$. The protagonist's dreams gain even more significance not only because of their symbolism, but also since it is a one-sided form of the contact made by the Ocean: while the earthlings are dreaming, the Ocean is reading their subconscious. American literary scholar Carlos Gutiérrez-Jones calls Kelvin's dreams a direct form of the contact between the hero and the Ocean, and it is hard to disagree with. The scholar considers the protagonist's preceding communication with Rheya as preparation for establishing direct contact ${ }^{46}$.

The world of Kris's bizarre dreams violates the laws of logic and mimesis. However, oneiric visions of the hero support the plot at the figurative-semiotic level. The fantastic nature of the conventionality of the novel allows us to perceive Kris's feelings literally. The reader senses that the hero's absolute reality is nothing but a dream, and what happens in it constituents his reality.

The imagery of dreaming incorporates two existential cores of Kris's world - his relations with Rheya and the problem of the contact with the Ocean. One can even say that the semiotics of dreams reflects the plot of the novel.

Kelvin admits that he retells just one of his dreams because of an acute feeling of fear that he experiences in the dream. The extreme emotional intesity of Kris's dreams leads to the idea that those phenomena embodied in the symbolism of dreaming are of the vital, basic value for the hero.

The semantics of double creation is in the center of protagonist's dreaming: "And recreated, I in my turn create: a face appears before me that I have never seen until now, at once mysterious and known" ${ }^{47}$. The hero feels both the creator and the object of the creation, he constitutes a whole with another creature, probably a woman: "The beat of our hearts combines ..." ${ }^{48}$. However, at the very moment, when this dual creature becomes

${ }^{45}$ D. Salynsky, the researcher of A. Tarkovsky's work, opts for the similar term "imaginative chronotope" when defining the world of heroes' imagination that involves dreams, visions, introspection, and the like. The film critic associates this chronotope with the images that focus on personal determinations, the hero's active choice and emphasizes the shutness and hermetism of this world (Д.Л. Салынский, Киногерленевтика Тарковского, Москва 2009, p. 77).

${ }^{46}$ C. Gutiérrez-Jones, Stranded Contacts: The Transformative Potential of Grief in Stanislaw Lem's Solaris, [in:] Suicide and Contemporary Science Fiction, Cambridge 2015, p. 69-70.

${ }^{47}$ S. Lem, Solaris..., p. 179.

${ }^{48}$ Ibid., p. 173. 
fully aware of its unity and reaches the harmony of coexistence with the other, everything collapses and the force, which created this dual pair, destroys it by turning it into a gelatinous mass.

In this imagery, Kris's relationship with the creator, the Ocean, which "reads" his very essence and which created Rheya for him, becomes obvious. It is interesting that the protagonist subconsciously considers the Ocean (and not Sartorius and Snow) the force which destroyed his wholeness. Apparently, distinctiveness and the teratomorphy of Rheya, with which Kris could not reconcile, bolster this irrational feeling.

In the same way, the plot is replicated by the dreams, in which the hero feels an experimental object in some destructive research, like the Solaris Ocean, devastated by the earthlings, and at the same time, he finds himself the object of cruel experiments of the Ocean. The dreams, however, are neither "clues" helping to solve the mysteries of the literary work nor fillers of the moments of indeterminacy. For instance, the reason why the Ocean creates the phantoms remains incomprehensible to both Kris and the readers of the novel themselves.

A. Tarkovsky in his film adaptation of Lem's novel vigorously applies a dreaming technique. The oneiric imagery of the film is the subject of special psychoanalytic and hermeneutic studies, in particular, Thorsten Botz-Bornstein ${ }^{49}$, Slavoj Žižek ${ }^{50}$, Dmitry Salynsky ${ }^{51}$, Ekaterina Savelyeva ${ }^{52}$ and others. Without going into a lot of interpretations of the film's oneirotopes, we will study two examples of how Tarkovsky converts the semantics of dreaming into another figurative system.

It can be said that, by substituting Lem's extraterrestrial images by "earthly" ones, Tarkovsky still encodes in the oneirotope of Kris's dream the semantics of creation in general, and the semantics of reduplicated consciousness in particular.

Thus, when falling asleep, sick Kelvin sees his double reflection in the mirror ceiling, though the second image is an incomplete, cropped copy of the first one ${ }^{53}$. The whole vision hints at the fact that Rheya originates in

${ }^{49}$ T. Botz-Bornstein, Films and Dreams: Tarkovsky, Bergman, Sokurov, Kubrick, and Wong Kar-Wai, Lexington 2007.

${ }^{50}$ С. Жижек, „Вещь из внутреннего пространства”, „Художественный журнал” 2001, no. 32, <http://www.guelman.ru/xz/362/xx32/xx3225.htm> [retrieved: 12.01.2020].

51 Д.Л. Салынский, op. cit.

${ }^{52}$ Е.А. Савельева, Картина П. Брейгеля «Охотники на снегу» как метафизический сон о Земле в фбльле А. Тарковского "Солярис", „Вестник Ленинградского государственного университета имени А.С. Пушкина: Научный журнал” 2015, vol. 2, no. 3, p. 233-241.

${ }^{53}$ In the first version of the film, a separate episode was shoot in the mirror room. Eventually, Tarkovsky cut this episode out and only figurative echoes remained, like the mentioned above reflection of Kris. 
Kris's memories. To this, the semantics of creation is metaphorized in the "earthly" images in the film. In particular, they are visualized in the scenes with his mother which merges with the image of Rheya (identical clothes and hairstyle), of the native house, in the images of earthy soil with sprouts brought down to the Station in an iron box.

According to Slavoj Žižek, the female characters of Tarkovsky, provocatively sexual, are "prone to hysterical insecurity". So, Tarkovsky manages to counterbalance them by the comforting image of the mother ${ }^{54}$. Tellingly, in Kris's dreams, the reader can see the duality of these images, equally combed and dressed. It can be interpreted as the embodiment of a certain fractal type of the Creation: Kelvin, as a physical and spiritual continuation of his mother, projects his image onto his beloved. His memory transforms the image in the way that, having been re-created by the Ocean, she looks alike of his mother. Yet, her nature is now dual: she physically excites (as a lover) and comforts (as a mother). In a broader sense, female images can be interpreted as a continuation of the fractal row from the image of the mother-Earth - a row in which the "planetary-terrestrial" dominant already loses its meaning.

Noteworthy, the indeterminacy of interpretations is in no way lessened in Tarkovsky's film, though he somewhat strengthens it, adding to the secrets of Lem's novel new mysteries rooted in the visual-audio code of the picture.

\section{Conclusion}

Thus, indeterminacy is an integral feature of the fictional world of Stanislav Lem's novel Solaris. In the work, the effect of indeterminacy acquires a specific nature and manifests itself both as a distinctive feature of the science fiction genre (with features of fantastic) as well as the writer's mastery in creating psychologically inspired narratives. Having applied the elements of the possible worlds theory by Marie-Laure Ryan to the analysis of the nature of indeterminacy in the novel, we can summarize that, in the textual actual world, it is realized through the mysterious inexplicable nature of the Ocean and its creatures - phantoms that visit the Station residents.

In Kris Kelvin's personal world, there are two main existential sources of uncertainty - his relationship with Rheya (both in her first and second incarnations) and the problem of the search of contact with extraterrestrial

${ }^{54}$ С. Жижек, op. cit.

225 Possible Worlds of Planet Solaris 
intelligence. The state of character's indeterminacy is organized here like a spiral loop becoming sharper at the beginning of the hero's work on Solaris and at the end of his relationship with Rheya when, having suffered psychological trauma, Kris experiences the state of indeterminacy again. But then it is concerned only to the problem of search of the contact with the Ocean.

At the figurative level, Kris's reflections on both his relations with Rheya and search for contact with the Ocean appear more vivid in the surreal visions of his dreams - within the Fantasy world of the protagonist. His dreams symbolically replicate the plot of the novel, as, for example, the dream where Kris feels himself at the same time an objects and subjects of the cruel experiments of the Ocean.

Besides, both in the text of Lem's novel and its adaptation by Andrei Tarkovsky, the complex of interlacing semantic codes leads to the constant questioning of their multiple semantics by the reader. In this way, the effect of receptive uncertainty is achieved, turning a highly talented work into a riddle without an unambiguous solution that fascinates the recipient with the charm of its secrets.

\section{BIBLIOGRAPHY}

Botz-Bornstein T., Films and Dreams: Tarkovsky, Bergman, Sokurov, Kubrick, and Wong Kar-Wai, Lexington 2007.

Csicsery-Ronay I.Jr., The Book Is the Alien: On Certain and Uncertain Readings of Lem's "Solaris", "Science-Fiction Studies" 1985, no. 12, (1), p. 6-21.

Doležel L., Heterocosmica. Fiction and possible worlds, Baltimore 1998.

Eco U., The Role of the Reader: Explorations in the Semiotics of Texts, Bloomington 1984.

Geier M., Stanislaw Lem's Fantastic Ocean: Toward a Semantic Interpretation of "Solaris", "Science-Fiction Studies" 1992, no. 19 (2), p. 192-218.

Gutiérrez-Jones C., Stranded Contacts: The Transformative Potential of Grief in Stanislaw Lem's Solaris, [in:] Suicide and Contemporary Science Fiction, Cambridge 2015, p. 44-77.

Hayles K.N., Chaos as Dialectic: Stanislaw Lem and the Space of Writing, "Chaos Bound: Orderly Disorder in Contemporary Literature and Science", Ithaca and London 1990, p. 115-140.

Jarzebski J., Stanislaw Lem: Rationalist and Visionary, przeł. Franz Rottensteiner,

"Science-Fiction Studies" 1977, no. 4, p. 110-126.

Krywak P., Fantastyka Lema: droga do "Fiaska", Kraków 1994.

Lem S., Fantastyka i futurologia, vol. 2, Kraków 1970.

Lem S., Solaris, Harvest Books 1987.

Lewis D., Counterfactuals, Cambridge 1973.

Pavel G.T., Fictional worlds, Cambridge 1986. 
Petric V., Tarkovsky’s Dream Imagery, “Film Quarterly” 1989, no. 43 (2), p. 28-34.

Ronen R., Possible Worlds in Literary Theory, Cambridge 1994.

Ryan M.-L., Possible Worlds, [in:] Living Handbook of Narratology, <https://www.lhn. uni-hamburg.de/node/54.html> [retrieved: 12.01.2020].

Ryan M.-L., The Modal Structure of Narrative Universes, "Poetics Today" 1985, no. 6 (4), p. 717-756.

Ryan M.-L., Bell A., Introduction: Possible Worlds Theory Revisited, [in:] Possible Worlds Theory and Contemporary Narratology, eds. A. Bell and M.-L. Ryan, Lincoln and London 2019, p. 1-43.

Swirski P., Solaris! Solaris. Solaris?, [in:] The Art and Science of Stanislaw Lem, ed. P. Swirski, Montreal \& Kingston-London-Ithaca 2008, p. 172-179.

Todorov T., The Fantastic: A Structural Approach to a Literary Genre, Cleveland-London 1973.

Жижек С., „Вещь из внутреннего пространства”, „Художественный журнал” 2001, no. 32, <http://www.guelman.ru/xz/362/xx32/xx3225.htm> [retrieved: 12.01.2020].

Кияк І.Б., Жанрові особливості фбантастики і футурологї̈ Станіслава Лела, Автореферат дисертації на здобуття наукового ступеня к.ф.н., Київ 2001.

Савельева Е.А., Картина П. Брейгеля "Охотники на снегу" как метафизический сон о Зелле в фбильле А. Тарковского “Солярис", „Вестник Ленинградского государственного университета имени А.С. Пушкина: Научный журнал” 2015, vol. 2, no. 3, p. 233-241.

Салынский Д.Л., Киногерленевтика Тарковского, Москва 2009. 
